\title{
DISSEMINATION OF DOCUMENTARY STAMP TAX BASED ON THE NEW LAWS IN SOUTH MERUYA
}

\author{
Debbie YOSHIDA and Rini MARLINA \\ Universitas Mercu Buana Jakarta \\ ${ }^{1}$ debbyoshida@gmail.com, ${ }^{2}$ rini_marlinapdg@yahoo.com
}

\begin{abstract}
Tax on documents or more commonly known as stamp duty, is a tax levied on documents. Documents that are subject to stamp duty are documents made as a tool to explain an event of a civil nature and documents used as evidence in court. The imposition of this Stamp Duty is based on the law established by the government, namely Law No. 13 of 1985. After 35 The year the government replaced the law on Stamp Duty with a new regulation, namely Law No. 10 of 2020, which came into effect on January 1, 2021. In this new law, several changes are adapted to the situation, good socioeconomic condition, law, and information technology. Because it is a new law, some people are not aware of any changes to this law.For this reason, it needs to be disseminated so that people are aware and able to use Stamp Duty by the provisions of the new law. The dissemination was carried out by the lecture method online using the Zoom application. The results can be seen from the questions given to the participants, which can be understood by the participants and answered correctly. This dissemination can further raise public awareness to know and understand the new regulations related to stamp duty.
\end{abstract}

Keywords: document, stamp duty, new regulations

\section{BACKGROUND}

Most of our state revenue comes from taxes. Based on Article 1 point 1 of Law Number 28 of 2007, tax is a mandatory contribution to the state owed by an individual or entity that is coercive under the law, without receiving direct compensation and meeting the people's needs. One type of tax is a tax on documents which we usually know as stamp duty.

Documents subject to Stamp Duty are documents made to explain an event of a civil nature and documents used as evidence in court. Taxes on documents or Stamp Duty collected by the government must have a legal basis; every type of tax is based on the law. Most of the existing Stamp Duty arrangements cannot answer the challenges of increasing state revenue. In addition, the situation and conditions that occur in the community have changed in the economic, social, legal, and information technology fields, so that the law needs to be replaced. One of them is the law on stamp duty which has not changed for 35 years.

On September 29, 2020, the DPR finally passed the new Stamp Duty Law, namely Law No. 10 of 2020 concerning Stamp Duty which took effect on January 1, 2021. The objectives of the new Stamp Duty Law are:

1. Optimizing state revenues to finance national development independently towards a prosperous Indonesian society.

2. Provide legal certainty in the collection of Stamp Duty.

3. Applying the imposition of Stamp Duty more fairly.

4. Align the provisions of the Stamp Duty with the provisions of other laws and regulations.

The new Stamp Duty Law consists of 12 chapters and 37 articles. The changes that have occurred are:

1. Expansion of Stamp Duty object, tariff adjustment

2. The nominal value limit of documents subject to Stamp Duty

3. Use of Electronic Seals and Other Forms of Seals Apart from Sticky Seals
4. Providing Facilities

5. Arrangements regarding sanctions.

This Stamp Duty is used for documents in the form of:

1. Letters of agreement and other documents made to be used as a means of proof regarding the creation, facts or circumstances of a civil nature;

2. Notary deeds including their copies;

3. Deeds made by Land Deed Making Officials (PPAT), including duplicates

In line with economic developments, both conventional and digital, of course, align with the increase in the volume of business transactions. As the basis of the transactions that occur, it requires evidence documents, both as legal evidence in civil law and as evidence of financial accounting in preparing financial statements and taxation.

From tax revenue data since 2013 Stamp Duty revenue has been relatively stagnant at $\mathrm{Rp} 4.42$ trillion. In 2019 as of October 2019 it was IDR 4.6 trillion (mediaindonesia.com). It can be seen that tax revenue from stamp duty is relatively low. Why is Stamp Duty receipts stagnant?. In the author's opinion, there are several possibilities:

1. Lack of adequate dissemination program

2. There is no administrative accountability mechanism, in contrast to Income Tax (PPh), Value Added Tax (PPN), and Luxury Goods Sales Tax (PPnBM).

3. The absence of a third party as a means of control such as Customs for Land and Building Rights Processing (BPHTB) carried out by Land Deed Making Officials (PPAT), and Land and Building Taxes (PBB) by Regional Governments for Land and Building Land and Building Taxes (P2) and Directorate General of Taxes for PBB Plantation, Forestry, Mining (P3) 
Of the three possibilities, socialization is a very strategic thing. Familiarizing people to live orderly with neat documentation is one of the main things as citizens in a state of law. Moreover, these documents can be used as legal evidence in legal proceedings in legal institutions such as the Police and Courts. Regarding documents related to economic and business transactions and related to social activities, major dissemination must be conducted sustainably with targeted patterns.

The role of universities as educational institutions that are obliged to serve the community deserves attention from the government, especially the Directorate General of Taxes, and needs to be continuously encouraged. Besides the university population spread across all regions and the Tax Service Office, synergistic cooperation needs to be strengthened so that the effectiveness of tax revenue from Stamp Duty can be optimized. The tendency of electronic transactions, in line with the role of information technology, the socialization pattern also needs to be packaged in such a way, regarding the layers of the digital society.

\section{Service Focus}

The community in the South Meruya region with a total of about 50,735 people (jakbarkota.bps.go.id), is a potential community because most of these people have businesses, employees, traders. The business activities they run include trading, printing, workshops, drug distributors, building materials stores, catering businesses, handicraft making businesses (bags, wallets), convection etc. Of course, in everyday life, stamp duty will be used on documents that are required to use stamp duty. Even today, many people use electronic documents, where electronic documents with the new stamp duty law include objects subject to stamp duty.

Based on our observations, many people in South Meruya are not aware of any changes in the stamp duty, thus encouraging us to disseminate to the community to implement the "Tri Dharma" of Higher Education by carrying out community service.

\section{Problem Identification}

In terms of business activities, including the creative economy, the development of information technology has given birth to electronic transactions so that contracts can be executed electronically. In the business world, efficiency is needed so that electronic documents are an option to increase efficiency.

The enactment of the new Stamp Duty law can provide convenience and administrative order in the management and supervision of state revenues. The goal of this activity is to make participants understand the new Stamp Duty law. In addition, they can be able to implement the provisions of the new Stamp Duty law so that can make it easier for the community to fulfill their obligations as good citizens who obey the law as a rule of law that regulates the life of the nation and state and participates in optimizing state revenues.

\section{Purpose}

The aim is to bring awareness to the public about optimizing state revenues with the new stamp duty rates change. Thus, it is expected to increase public understanding of the use of Stamp Duty, including for transactions using electronic documents. It also raises public awareness to understand the laws and regulations regarding Stamp Duty. For Mercu Buana University, it can increase its role as an education center, not only for students in the Mercu Buana University campus but also for its environment.

\section{METHOD}

\section{Activity Method}

Participants in this socialization are people in the Meruya Selatan sub-district, West Jakarta, consisting of business actors, village officials, youth, entrepreneurial mothers, and the general public by socializing the new stamp duty regulations that are used on paper documents and electronic documents that are adapted with technological developments.

This tax dissemination on documents or Stamp Duty was designed using an online lecture method using the Zoom application, and material for each participant was distributed about Stamp Duty.

1. Explaining the tax material on documents or Stamp Duty by the new Stamp Duty laws. Each participant is given material that is used to help understand the Stamp Duty according to the new Stamp Duty law by sharing it via WAG (WhatsApp Group)

2. Explain examples of the use of documents subject to Stamp Duty. In this session, participants get an explanation and simulation of how to use the documents levied by the Stamp Duty

3. Discussion and Q\&A. Provide opportunities for participants to discuss and ask questions about the new Stamp Duty law

\section{Implementation of Activities}

The activity of providing tax material on documents in accordance with the new laws and regulations is carried out in the form of socialization. This activity is related to efforts to provide an understanding of changes in tax regulations on documents and the use of Stamp Duty in accordance with the latest regulations so that people can use Stamp Duty in accordance with the new applicable rules.

This service activity is carried out by:

1. Inviting the community in the South Meruya Village consisting of business actors, entrepreneurial mothers, and other communities.

2. The socialization given is done online by conducting webinars via zoom. For this reason, we created a flyer where people who will take part in the activity must first register via the link we provide. 
3. The time for the implementation of the activity will be on February 8, 2021.

4. Socialization materials were also distributed to participants via WhatsAppGroup to make it easier for participants to understand the material we conveyed.

\section{RESULT AND DISCUSSION}

The Service Team does service to the people of South Meruya by providing socialization of taxes on documents or Stamp Duty in accordance with the new laws and regulations in the form of expansion of Stamp Duty objects, adjustment of tariffs, limits on the nominal value of documents subject to Stamp Duty, provision of facilities and electronic seals. Thus, you can find out the latest regulations for Stamp Duty

The following are the Achievements of Outcomes of community service activities to be carried out:

Table 1. Achievements Outcomes of community service activities

\begin{tabular}{|c|c|c|}
\hline No & Outcome Types & $\begin{array}{c}\text { Achievement } \\
\text { indicators }\end{array}$ \\
\hline 1 & $\begin{array}{l}\text { Scientific publications in journals } \\
\text { with ISSN/proceedings }\end{array}$ & $\sqrt{ }$ \\
\hline 2 & $\begin{array}{l}\text { Publication in mass media (print / } \\
\text { electronic) }\end{array}$ & $\sqrt{ }$ \\
\hline 3 & $\begin{array}{l}\text { Increased turnover for partners } \\
\text { engaged in the economy }\end{array}$ & - \\
\hline 4 & $\begin{array}{l}\text { Increasing the quantity and quality of } \\
\text { products }\end{array}$ & - \\
\hline 5 & $\begin{array}{l}\text { Improvement of community values } \\
\text { (art and culture, social, politics, } \\
\text { security, peace, education, health }\end{array}$ & $\sqrt{ }$ \\
\hline 6 & Publications in international journals & - \\
\hline 7 & $\begin{array}{l}\text { Services, social engineering, methods } \\
\text { or systems, products/goods }\end{array}$ & - \\
\hline 8 & New TTG innovations & - \\
\hline 9 & $\begin{array}{l}\text { Intellectual property rights (Patent, } \\
\text { Simple Patent,Copyright,, Trademark, } \\
\text { Trade Secret, Industrial Product } \\
\text { Design, Plant Variety Protection, } \\
\text { Integrated Circuit Topographic } \\
\text { Design Protection }\end{array}$ & - \\
\hline 10 & Textbook & - \\
\hline
\end{tabular}

\section{Activity Implementation}

This activity is the Mercu Buana University Community Service Program. During the implementation, it requires the linkage of the Community Service Institute with the surrounding community, especially the community around the West Jakarta area. The target audience was the community in the South Meruya Village, West Jakarta.

1. The implementation of the socialization begins with a speech given by the Dean of the Faculty of Economics and Business, Mercu Buana University where the community service activities carried out are expected to increase the knowledge and insight of the people of South Meruya. participate in this activity even though it is done online.

2. Next, the Service Team introduces themselves and explains the purpose of the community service activities
3. We provide socialization about taxes on documents or what we usually know as Stamp Duty under the new laws and regulations. Tax on documents in accordance with this new law and regulation will take effect on January 1, 2021.

4. The community service team provides a question and answer opportunity to provide opportunities for participants who do not understand the Stamp Duty regulations

5. Distributing questionnaires to participants through the link filled in as feedback on the implementation of community service activities.

6. The activity was closed by giving door prizes to participants who could answer questions related to the material being socialized

\section{Discussion}

In theimplementation of this community serviceactivity, the response from the participants was favorable. This activity, which was conducted virtually due to the social restriction, did not discourage participants from participating in this event. This can be seen from the punctual attendance and engagement of the participants. There were no significant obstacles during the implementation.

The results achieved by the community service participants are favorable. They can quickly understand the material because the material that is socialized is easy to understand and directly related to the efforts and activities of the participants who use documents levied on stamp duty.

The relevance of this community service activity can increase the knowledge of business actors, entrepreneurial mothers, and other participants. By providing the dissemination of documentary stamp tax according to the latest regulations, participants can find out the amount of tax on new documents according to the latest regulations and starting January 1, 2021, which is Rp. IDR 10,000 and can already use a new stamp, while the old stamp can still be used until December 2021 with a minimum rate of IDR 9000 (Stamp IDR 3,000 x3 or Stamp IDR 3,000+ IDR 6,000). In addition to tariff adjustments, there is also an expansion of the Stamp Duty object, the limit on the nominal value of the document subject to the Stamp Duty, the provision of facilities and an electronic stamp duty.

As for the service team, they can apply the knowledge they have learned. As a follow-up to this service, it is hoped that business actors, entrepreneurial mothers, and other participants can easily use the stamp duty in accordance with the new regulations that apply.

At the end of the event, we distributed questionnaires to the participants to fill out as feedback on the implementation of community service activities. The participants felt the benefits and agreed to hold a community service event because it could add insights to them. 


\section{CONCLUSION AND SUGGESTIONS}

\section{Conclusion}

During the implementation of this community service activity, it is in the form of tax socialization on documents based on the new laws and regulations that can be carried out properly and run smoothly. Activities were carried out online through this zoom because it is still a pandemic period.

The participants were enthusiastic about asking questions because they were related to new regulations. Many were directly related to documents that required Stamp Duty and transactions carried out in businesses that required Stamp Duty.

The participants gained additional knowledge about Stamp Duty. The socialization carried out was easy to understand and directly related to all participants and business transactions of the participants' activities using the documents owed by Stamp Duty.

\section{Suggestions}

a. Participants are advised to follow the development of Stamp Duty legislation, both through print and electronic media.

b. It is recommended for the Directorate General of Taxes to conduct massive and sustainable socialization.

c. The socialization provided is expected to encourage participants to comply with tax regulations on the latest documents for smooth business and other activities related to taxes on documents not to experience difficulties if one day they are in trouble with the law.

\section{BIBLIOGRAPHY}

Ilyas, Wirawan,Suhartono, Rudy. (2017). Perpajakan (3rd ed.). Mitra Wacana Media, Jakarta.

https:/jakbarkota.bps.go.id/

https://mediaindonesia.com/ekonomi/272257/djp-sebutpenerimaan-bea-materai-stagnan-selama-6-tahunterakhir 